\title{
Kala Dalam Bahasa Melayu Manado
}

\author{
John A. Pattipeluhu \\ johnpattipeiluhu@gmail.com \\ Leika M.V. Kalangi \\ Pascasarjana \\ Universitas Sam Ratulangi
}

\begin{abstract}
This research aims to understand and to describe the process and rules of the tenses form in Manado Malay language. This research is conducted in Manado which is almost all the civilians use Manado Malay language as their daily communication.

This Research uses qualitative descriptive method and structural linguistics method as an approaching to do this research.The data collecting was in terms of recording and interviewing with informan and analyzed by Miles and Huberman model of data analysis such as data reduction, data display and data conclusion.

The result shows that there are three forms of tenses in Manado Malay languages. Those are present, past and future. The present tense is form by a prefix ba-which is bound to a verb; past tense is formed by a partikel so and followed by a verb and; future tense is formed by partikel mo and followed by a verb.
\end{abstract}

Keywords: tenses, process, Manado-Malay, language

\section{PENDAHULUAN}

Manusia adalah makhluk sosial yang selalu berinteraksi dengan sesama manusia lain dalam semua segi kehidupannya. Interaksi yang dilakukan oleh manusia tidak hanya menggunakan kegiatan fisik saja tetapi juga dengan menggunakan bahasa yang bisa dipahami oleh para penutur ata pengguna bahasa. Oleh karena itu, fungsi bahasa secara singkat ialah alat yang digunakan manusia untuk menyampaikan ide, pesan, maupun ungkapan perasaan yang ditujukan kepada orang lain. Hal ini sejalan dengan apa yang disampaikan oleh Kridalaksana (2001:27), bahasa adalah sistem lambang bunyi yang arbitrer yang dipergunakan oleh para anggota masyarakat untuk bekerjasama, berinteraksi dan 
mengidentifikasikan diri. Di dalam proses komunikasi, ada sistem tanda atau lambang yang membentuk struktur bahasa. hubungan antara pola kalimat dan arti yang tersirat di dalamnya merupakan sesuatu hal yang kompleks. Kenyataan ini terjadi di setiap bahasa di dunia yang berimbas pada dibutuhkannya penjelasan mengenai arti dari setiap bentuk dan pola kalimat. Pembahasan pola kalimat yang disertai dengan maknanya dibutuhkan analisis suatu kalimat berdasarkan situasi yang melingkupinya atau bisa dikatakan dengan mempertimbangkan konteks ekstra-linguistiknya. Lebih lanjut Bache menyatakan "situation, here is used as a cover term for all sorts of states, events, actions, process, activities, etc" (1997: 119). Konteks ekstralinguistiknya atau konteks situasi biasanya akan dikaitkan dengan adanya penanda waktu apabila digunakan untuk menggambarkan hubungan antara pola kala dan aspeknya. Pada dasarnya konsep waktu dalam setiap kebudayaan jika dilihat dari sisi bahasa sangatlah berkaitan dengan bagaimana suatu peristiwa atau kejadian ditempatkan dalam garis waktu dan dinyatakan di dengan menngunakan konsep bahasa.

Pada umumnya, penanda kala dalam suatu bahasa adalah sama dengan beberapa bahasa lainnya, misalkan adanya perubahan morfologis pada pembentukannya ataupun penanda leksikal pada umumnya. Pembahasan penanda kala tentu tidak akan cukup dalam sebuah kajian saja melainkan perlu adanya intensifitas dan kajian yang lebih luas lagi. Dalam meneliti tentang kajian kala dari suatu bahasa, dapat ditinjau dari berbagai segi, misalnya dari segi bentukan morfologisnya maupun dari perilaku sintaksisnya, dan perilaku semantisnya (Moeliono, 1988:76). Dalam tulisan ini hal tersebut akan coba diteliti dan dibahas tentang kala dalam Bahasa Melayu Manado.

Bahasa Melayu Manado digunakan sebagai alat komunikasi dalam hampir semua aktivitas kehidupan di Sulawesi Utara. Bahasa Melayu Manado dituturkan penduduk di Kota Manado, Bitung, Tomohon, , Kabupaten Minahasa, Minahasa Selatan, Minahasa Utara, Minahasa Tenggara Kabupaten Bolaang Mongondow dan Provinsi Gorontalo. Bahasa Melayu Manado secara selintas memiliki kesamaan dengan bahasa Melayu di kawasan timur Indonesia seperti bahasa Melayu Papua, bahasa Melayu di Ambon, bahasa Melayu di Ternate, dan bahasa Melayu di Nusa Tenggara (Supardi, 2011:193). Bahasa Melayu Manado banyak 
mendapat pengaruh dari bahasa-bahasa di Erop seperti bahasa Portugis, Spanyol, Belanda, Perancis dan Inggris dibandingkan dengan bahasa Melayu lainnya di Indonesia. Dalam beberapa tahun belakangan sudah ada beberapa penelitian tentang bahasa Melayu Manado seperti penelitian yang dilakukan oleh Najoan, dkk (1981) yang mendiskripsikan morfologi dan sintaksis bahasa Melayu Manado yang mana bertujuan untuk mencari sifat atau cirri morfologi dan sintaksis bahasa ini. Penelitian berikutnya yang dilakukan oleh Rattu (2002) yang memaparkan tata bahasa Melayu Manado. Hidayat (2013) menulis tentang pronomina dalam Bahasa Melayu Manado. Diskripsi dan kajian terhadap bahasa Melayu Manado masih sangat terbatas sehingga dibutuhkan lagi pendalaman dan pengembangan dalam berbagai aspek kebahasaan guna melengkapi, menemukan dan menjelaskan fenomena-fenomena yang ada dalam bahasa Melayu Manado. Oleh karena hal tersebut, penelitian ini hadir untuk membahas tentang konsep kala dalam bahasa Melayu Manado.

\section{Perumusan Masalah}

Rumusan masalah berdasarkan latar belakang pada penelitian ini ialah;

1. Apa saja bentuk kala dalam bahasa Melayu Manado?

2. Bagaimana pembentukan kala dalam bahasa Melayu Manado?

\section{Tujuan Penelitian}

1. Memahami bentuk kala dalam bahasa Melayu Manado.

2. Menguraikan pembentukan kala dalam bahasa Melayu Manado

\section{Manfaat Penelitian}

Ada dua manfaat yang dihadirkan oleh penelitian ini yaitu manfaat teoritis dan manfaat praktis.

\section{Manfaat Teoritis}

Secara teoritis, penelitian ini diharapkan mampu mendeskripsikan secara jelas mengenai bentuk dan pembentukan kala dalam bahasa Melayu Manado.

2. Manfaat Praktis

Secara praktis, penelitian ini diharapkan bermanfaat bagi peneliti selanjutnya terutama di bidang linguistik dalam proses pembelajaran tentang kala. 


\section{TINJAUAN PUSTAKA}

Dalam bagian ini, penulis akan menyampaikan beberapa tinjauan pustaka mengenai kala yang telah diteliti. Penyampain hasil penelitian pada penelitian kala yang terdahulu diharapkan dapat memperjelas permasalahan dari kala dan membedakan penelitian kala bahasa Melayu Manado dengan penelitian-penelitian terdahulu serta mengisi bagian-bagian yang belum diteliti sebelumnya. Dalam beberapa tahun terakhir ini sudah ada beberapa penelitian mengenai kala suatu bahasa:

1. Pateda (2012) yang dalam Disertasi-nya meneliti tentang "Dimensi Aspek dikaitkan dengan kelas kata, jumlah dan penanda arah dalam bahasa Gorontalo" Disertasi, Program Pascasarjana Universitas Sam Ratulangi Manado. Pada penelitian ini sumber data terdiri atas data lisan yang diperoleh dari pemangku adat, tokoh masyarakat dan tokoh pendidikan (pensiunan). Sedangkan data tulisan bersumber pada wacana dalam Buku Pembelajaran Muatan Lokal Bahasa Gorontalo untuk SD Kelas I-VI, semester I-II (Pateda dan Pulubuhu, 2006) daan wacana dalam Buku Pelajaran Muatan Lokal Bahasa Gorontalo untuk SLTP kelas 7,8, 9 semester I-II (Pateda dan Pulubuhu, 2008). Metode yang digunakan ialah metode

Hasil dari penelitian ini ialah bahwa keterkaitan aspek dan kelas kata ditandai oleh (1) penambahan partikel di depan kelas kata, (2) dibentuk melalui perubahan bentuk kelas kata melalui proses afiks dan pengulangan, dan (3) melalui penderetan dua atau lebih kata yang mempunyai bentukan yang sama. Keterkaitan aspek dan kala ditandai oleh (1) penggunaan afiks sebagai penanda kala akan dan lampau, reduplikasi verba sebagai penanda kala sedang (2) aspek dapat dibentuk pula melalui reduplikasi, dan (3) penggunaan kata bantu berfungsi untuk memperkuat makna. Keterkaitan aspek dan jumlah ditandai oleh sistem berikut yaitu (1) aspek dibentuk melalui pola struktur kalimat yakni: partikel ma + kata benda + jumlah benda, (2) aspek ditandai oleh kombinasi prefix molo-, lolo-, le'I, he po'o, hi, hi poti- atau hipo- / -a, dan reduplikasi.(3) penunjuk jumlah tak tentu ialah perulangan kata dasar ditambah dengan akhiran -walo, woalo, atau -yaalo. Keterkaitan aspek dan penanda arah ditandai oleh sistem sebagai berikut, (1) Aspek dibentuk dengan menggunakan afiks mohi-, moti- (ti), poti- (ti-), (io-), hi-/- 
$w a$, dan $-a$ pada kata benda yang bertransposisi menjadi kata kerja dan diikuti penanda arah. (2) Aspek dibentuk pula dengan menggunakan partikel seperti he atau $h i$ diikuti oleh bentukan mopo'o, - $a$ dan ditambah kata penunjuk arah.

2. Penelitian selanjutnya dilakukan oleh Condro Nur Alim pada tahun 2011. Penelitian yang berjudul "Kala dan Aspek Bahasa Inggris serta Masalah Penerjemahanya (Sebuah Analisis tentang Fungsi Kala dan makna Aspek Verba dalam Novel The God of Small Things serta Padanan Penerjemahannya dalam Bahasa Indonesia)" ini mendeskripsikan kala dan aspek sebagai pemarkah waktu dalam novel bahasa Inggris tersebut. Selain itu, penulis tersebut juga mendeskripsikan makna aspektualitas verba dalam novel yang sama, serta mendeskripsikan penerjemahan kala dan aspek dari bahasa Inggris ke dalam bahasa Indonesia agar diperoleh kesepadanannya. Hasil dari penelitian tersebut dibagi ke dalam tiga bagian. Bagian pertama tentang kala. Dalam novel tersebut ditemukan banyaknya penggunaan kala mutlak, yang terdiri dari kala mutlak present, kala mutlak past, dan future. Pada bagian aspek, ditemukan hampir seluruh aspek dalam bahasa Inggris digunakan dalam novel tersebut, yaitu progressive, perfect, perfect-progressive, dan aspek simple.

3. Penelitian berikutnya yaitu yang dilakukan oleh Titien Rostini. Penelitian ini menggunakan kalimat-kalimat berbahasa Jepang sebagai data. Fokus penelitian ini ialah menemukan persamaan dan perbedaan antara kala dan aspek dalam bahasa Jepang. Hasil analisis menunjukkan bahwa segmentasi dalam tataran verba bahasa Jepang dapat dikaji melalui pendekatan etik dan emik yang memiliki hubungan fungsional dengan cara menentukan satuan-satuan kontrastif minimal sebagai dasar deskripsinya. Pendekatan yang bersifat emik menunjukkan bahwa pembentukan unsur kata dengan morfem terikat morfologis seperti gabungan -te, -ta, dan -I memiliki fungsi dan makna, sedangkan melalui pendekatan etik menunjukkan bahwa oposisi bentuk-bentuk $\{$-te $\} /\{$-ta $\}$ berdistribusi parallel dengan alomorf-alomorf (varian): [-nde]/[-nda], [-ite]/[-ita], [-ide]/[-ida], [shite]/[shita], dan bunyi geminate [tte]/[-tta]. Secara fonologis, tataran verba yang melibatkan oposisi fonem /-e/ dan /-a/ dalam bentuk \{-te\} dan \{-ta\} tersebut merupakan perbedaan minimal (minimal pairs) yang menunjukkan oposisi kala: past (-ta) dan nonpast (-te). Fonem segmental yang direalisasikan dalam bentuk 
morfem terikat morfologis tersebut merupakan penyebab timbulnya asimilasi dan berada pada posisi yang berdekatan, yaitu sebelum segmen yang mengalami asimilasi yang dalam hal ini adalah akar. Oleh sebab itu, kelinieran dalam tataran fonem setelah terjadi proses asimilasi tersebut merupakan bentuk asimilasi progresif atau perseveratif yang bersifat parsial dan dapat diamati melalui gejala perubahan bunyi yang menyangkut pelesapan, penambahan, permutasi, perubahan urutan segmen, ciri-ciri distingtif, dan penyatuan segmen.

4. Penelitian berikutnya dilakukan oleh Mutia Rany (2011) yang berjudul "Aspek dan Kala dalam Bahasa Arab." Penelitian ini bertujuan untuk mengetahui dan menjelaskan jenis-jenis aspek dan kala dalam bahasa Arab. Data diambil dari ayat-ayat Kitab Suci Al-Quran yang memberikan kesimpulan bahwa jenis-jenis aspek dalam bahasa Arab berkaitan dengan permasalahan kala, antara lain aspek perfektif dan aspek imperfektif. Aspek perfektif biasanya diungkapkan dengan menggunakan verba ma:di yang juga berkala lampau dan aspek imperfektif diungkapkan dengan verba muda:ri. Pada bahasa Arab hanya terdapat dua bentuk kala sebagai kategori verba yang diungkapkan secara gramatikal yaitu verba ma:di yang berkala lampau dan verba muda:ri yang berkala kini. Meskipun dalam konsep verba bahasa Arab hanya terdapat dua konsep kala yang pengungkapannya secara gramatikal, akan tetapi bahasa Arab mengenal tiga waktu kebahasaan yang universal yaitu lampau, kini dan mendatang.

Dari beberapa penelitian yang telah dipaparkan dapat dilihat bahwa penelitian-penelitian tersebut cukup berbeda dengan penelitian ini yang berjudul "Kala Dalam Bahasa Melayu Manado" ini. Penelitian ini berfokus pada pengungkapan makna dan bentuk kala yang dibahasa secara struktural. Disamping objek kajian penelitian yang berbeda, penelitian ini juga merupakan penelitian yang murni dilakukan secara deskriptif linguistik yang menggambarkan bahasa Melayu Manado sesuai dengan realita - dalam hal ini data-data yang diambil ialah tuturan-tuturan yang diucapkan oleh penutur bahasa tanpa ada rekayasa penggunaan bahasa. 


\section{KERANGKA TEORITIS}

\section{Linguistik Struktural}

Penelitian ini bersifat deskriptif dengan menggunakan teori linguistic struktural yang memandang bahasa sebagai unit-unit yang tersusun atau sebagai suatu struktur. Bloomfield (1933:20) berpendapat bahwa teori struktural memandang bahasa sebagai satu kesatuan sistem yang memiliki sistem tersendiri. Dengan kata lain, setiap bahasa mempunyai sistem fonologi, morfologi dan sintaksis. Sejalan dengan konsep dari Bloomfield, Kridalaksana (2008:16) berpendapat bahwa linguistik struktural ialah pendekatan dalam penyelidikan bahasa yang menganggap bahasa sebagai sistem yang bebas. Sistem dan struktur suatu bahasa merupakan wujud mendasar bagi sebuah bahasa karena sesederhana apapun sebuah teks, akan dapat ditemukan sistem yang mengatur pola-pola strukturnya (Marnetti, 2011:90).

\section{Kala}

Istilah kala (tense) merupakan istilah yang diambil dari bahasa Yunani dari bahasa 'khronos' atau bahasa Latin 'tempus' (Lyon. 1968:304). Kajian kala merupakan kajian tentang hal yang berkaitan dengan peristiwa, status atau tindakan yang dinyatakan oleh verba dan bergantung pada konteksnya pada saat pembicaraan terjadi sebagaimana dikatakan oleh Saeed (2000:115) bahwa "Tense is said to be a diectic system, since the reference point for system is usually the act of speaking". Sedangkan Bache (1997:250) menitikberatkan pada persoalan hubungan referensial antara, peristiwa yang sudah berlalu, saat ini, dan saat yang akan datang. "what is referred to as a present situation today maybe referred to as a past situation tomorrow and might have been referred to as a future situation yesterday”. Sementara itu J.W.R. Verhaar mengungkapkan bahwa kala mempermasalahkan pada titik waktu dalam hubungannya dengan saat penuturan dan ditentukan sesuai apa yang dikatakan dalam verbanya. Dari beberapa uraian para ahli di atas maka secara umum, sistem kala itu bersifat universal, di mana berlaku untuk segala bahasa. Terkadang kita sangat sulit membedakan antara konsep waktu dengan konsep kala, sebab menurut Comrie (1985:7) ide untuk menempatkan suatu situasi pada garis waktu sebenarnya merupakan notasi 
konseptual sehingga hal ini memungkinkan terjadinya perbedaan antara bahasa yang satu dengan bahasa yang lainnya. Untuk menghindari ambiguitas tersebut, kita perlu memahami bahwa waktu dan kala adalah konsep yang sangat berbeda. Hal ini didasarkan pada pernyataan Jespersen dalam bukunya Essential of English Grammar, yang menyatakan bahwa konsep waktu merupakan konsep umum yang ada pada semua bahasa di seluruh dunia, sedangkan konsep kala bervariasi antara satu bahasa dengan bahasa lainnya dan merupakan ekspresi linguistik yang bersifat time-relation (Jespersen, 1993:230). Dalam ilmu bahasa, istilah waktu termasuk kategori semantik sedangkan kala termasuk ke dalam kategori gramatikal (Hoed, 1992:3). Dengan mengacu pada pengertian kala sebagai kategori gramatikal yang berfungsi untuk menempatkan suatu situasi dalam suatu waktu, maka sebagain besar ahli mengelompokkan kala dalam tiga kategori yaitu present, past, dan future (Jespersen 1993, Lyons, 1968, Comrie 1985, Quirk, 1985 dan Bache 1997). Lebih lanjut, Bache (1997:245) mendefenisikan kategori kala secara lebih detail yaitu sebagai berikut:

a. situasi lampau (past) adalah situasi yang secara temporal berada sebelum waktu sekarang.

b. Situasi kini (present) adalah situasi yang secara temporal berada pada waktu sekarang.

c. Situasi akan datang (future) adalah situasi yang secara temporal berada pada waktu setelah sekarang.

Fungsi kala dalam menempatkan peristiwa dalam waktu berkaitan erat dengan satuan rujukan waktu. Pemahaman mengenai satuan rujukan waktu sangatlah penting untuk memahami sistem kala dalam memahami maksud tuturan. Menurut Comrie (1985: 36-65), suatu rujukan waktu dibedakan menjadi tiga yaitu; suatu rujukan waktu mutlak, suatu rujukan waktu relatif dan suatu rujukan waktu mutlak relatif.

a. Suatu rujukan waktu mutlak adalah rujukan waktu yang menggunakan waktu kini (present moment) sebagai pusat deiksis. Pusat deiksis ini juga disebut titik referensi sehingga suatu rujukan waktu mutlak dibagi menjadi tiga yaitu peristiwa yang terjadi sebelum, bersamaan atau sesudah waktu kini sebagai pusat deiksis. 
b. Suatu rujukan waktu yang menggunakan titik referensi lain selain waktu sekarang (present moment) sebagai pusat deiksis.

\section{METODE PENELITIAN}

Data dikumpulkan dengan menggunakan data primer dan data sekunder, Data primer dalam penelitian ini diperoleh melalui data rekaman tuturan para penutur bahasa Melayu Manado yang telah terdokumentasi sedangkan data sekunder didapat dari buku-buku yang berhubungan dengan penelitian ini. Pengumpulan data dalam penelitian ini menggunakan teknik pengumpulan data linguistik struktural seperti yang dikemukan oleh Subroto (2007) yaitu teknik rekam yaitu perekaman pemakaian bahasa lisan yang bersifat spontan - bahasa yang digunakan secara alami dan tidak dibuat-buat. Situasi disaat perekaman tidaklah diketahui oleh informan sehingga data yang didapat ialah benar-benar data bahasa yang dipergunakan secara alamiah. Teknik yang kedua ialah teknik kerja sama dengan informan. Informan dalam penelitian ini ialah para pembicara asli bahasa Melayu Manado yang berkemampuan memberikan informasi kebahasaan kepada peneliti - dalam hal ini penelitilah yang merencanakan pertanyaan-pertanyaan yang berhubungan dengan penggunaan kala dalam tuturan bahasa Melayu Manado. Selanjutnya, data-data yang telah dikumpulkan akan dianalis guna menemukan dan memahami bentuk dan pembentukan kala dalam bahasa Melayu Manado. Teknik pengolahan data menggunakan menggunakan model dari Miles dan Huberman yaitu data reduksi, data display dan kesimpulan.

\section{HASIL DAN PEMBAHASAN}

Hampir semua bahasa di dunia mengenal tiga jenis waktu kebahasaan yaitu waktu kebahasaan kini, waktu kebahasaan lampau, dan waktu kebahasaan mendatang. Pada bagian ini akan dibahas mengenai bentuk-bentuk kala serta pembentukannya. Berikut ini adalah tuturan-tuturan yang menggunakan kala.

\section{Kala Kini}

Pada bahasa Melayu Manado, prefiks ba memiliki makna kelampauan yang akan muncul sebagai penanda kala kini. Berikut ini ialah tuturan-tuturan yang 
menggunakan rujukan waktu kini atau peristiwa yang terjadi bersamaan dengan pusat deiksis.

\section{Kita da bamanjae baju.}

'Saya ada sementara menjahit baju'.

\section{Dia da basosapu.}

'Dia ada sementara menyapu.'

\section{Da orang batangka ikang di koala.}

'Ada orang sementara tangkap ikan kolam.'

Kalimat pada contoh diatas menjelaskan bahwa kalimat ini menggunakan unsur partikel $d a$ yang diikuti kata kerja yang didahului prefiks ba untuk menunjukkan bentuk kala kalimat-kalimat tersebut yang berarti keadaan suatu kejadian atau perbuatan yang sementara dilakukan. Jika prefiks $b a$ - tidak ditambahakan dalam verba yang membentuk tuturan tersebut maka makna kala tersebut pun menjadi berubah dari makna kala waktu sekarang menjadi makna kala waktu lampau. Sebagai contoh:

4. Kita da manjae baju.

'Saya ada menjahit baju.'

\section{Dia da sosapu.}

'Dia ada menyapu.'

Jika kita melihat unsur pembentuk dari kedua contoh kalimat 1 dan 2 dan membandingkan dengan kalimat 3 dan 4 maka bisa ditarik kesimpulan bahwa prefiks $b a$ sangatlah penting dalam pembentukan kala.

$$
\begin{array}{ccc}
\text { Kita } & d a \quad \text { bamanjae } & \text { baju } \\
\mathrm{S}+ & \text { Partikel }+ & \text { prefiks }+\mathrm{V}+\mathrm{O}
\end{array}
$$




$$
\begin{gathered}
\text { Kita da manjae baju } \\
\mathrm{S}+\text { Partikel }+\mathrm{V}+\mathrm{O}
\end{gathered}
$$

Prefiks $b a$ - merupakan morfem terikat yang memiliki fungsi sebagai penanda kala waktu atau kejadian yang terjadi di masa sekarang jika digabungkan dengan verba dalam bahasa Melayu Manado. Prefiks $b a$ - ditujukan untuk mengungkapkan sebuah tindakan yang berdurasi sejak tindakan tersebut dimulai hingga pada waktu pengujaran.

\section{Kala Lampau}

Pada bahasa Melayu Manado, partikel so memiliki makna kelampauan yang akan muncul sebagai penanda kala lampau. Hal ini bisa dilihat pada tuturan-tuturan yang menggunakan rujukan waktu lampau atau peristiwa yang terjadi sebelum pusat deiksis.

\section{Io, so klar karja dia di om Beni pe ruma}

'Ya, sudah selesai kerja dia di om Beni pe ruma'

\section{Kong skrang so bakarja ulang pa depe bos}

'sekarang sudah bekerja kembali di atasannya.'

\section{Kita so smokol}

'Saya sudah smokol'

Pada kalimat 6, 7 dan 8 dinyatakan sebagai tuturan kalimat yang mengandung arti masa lampau - yaitu aktifitas atau kejadian yang sudah terjadi. Adanya partikel so dalam tuturan tersebut menyatakan bahwa kegiatan yang dilakukan maupun dimaksudkan oleh penutur telah terjadi. Jika dalam tuturan tersebut tidak ada partikel so maka unsur waktu atau kala akan sulit diketahui sehingga ketika berbicara mengenai kejadian yang terjadi di masa lampau, biasanya partikel so selalu ada untuk membentuk kala lampau. 
Dilihat dari proses pembentukan kala masa lampau ini, partikel so selalu ada dan ditempatkan sebelum verba hal ini bisa dilihat dari struktur kalimat pada contoh berikut:

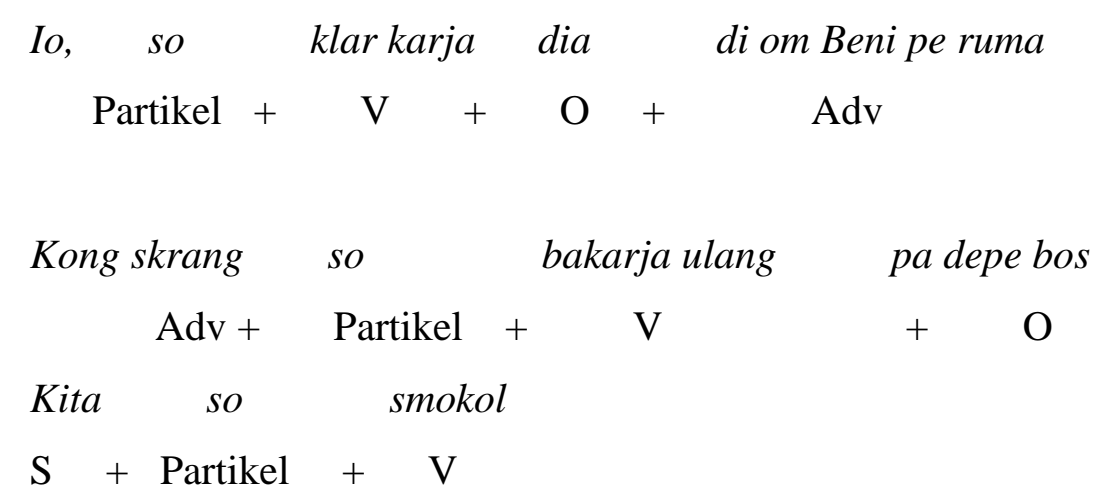

3. Kala Mendatang.

Berikut ini ialah tuturan-tuturan yang menggunakan rujukan waktu mendatang atau peristiwa yang terjadi sesudah pusat deiksis.

9. Besok mo pi ka Manado.

'Besok, akan pergi ke Manado.'

\section{Kita mo momasa ikang.}

'Saya akan memasak ikan.'

\section{Torang mo pasiar pa depe rumah}

'Kami mau berkunjung ke rumahnya.'

Pada tuturan 9, 10 dan 11 dinyatakan sebagai kalimat yang mengandung unsur kala di masa yang akan datang. Di dalam tuturan diatas, partikel mo merupakan pembentuk makna kala. Dari unsur pembentukannya, partikel mo juga hadir sebelum verba. Hal ini juga sama dengan sistem pembentukan kala pada kala masa sekarang dank ala masa lampau.
Besok mo pi ka Manado.
$\mathrm{Adv}+$ Partikel $+\mathrm{V}+\mathrm{O}$
Kita mo momasa ikang.
$\mathrm{S}+$ Partikel $+\mathrm{V}+\mathrm{O}$




$$
\begin{array}{cccc}
\text { Torang } & \text { mo } & \text { pasiar } & \text { pa depe rumah } \\
\mathrm{S}+\text { Partikel } & +\mathrm{V}+ & \mathrm{O}
\end{array}
$$

\section{Validasi}

Dari data-data diatas, bisa didefinisikan bahwa dalam bahasa Melayu Manado juga terdapat kala yang mana bisa diungkapkan melalui penggunaan prefiks $b a$ sebagai pembentuk kala kini, partikel so- untuk membentuk kala lampau dan partikel mo untuk kala mendatang. Tetapi untuk menguji dan mengetahui apakah prefiks $b a$-, partikel so dan mo adalah satuan-satuan lingual yang membentuk kala maka perlu dilakukan validasi. Cara untuk melakukan validasi ialah menggunakan teknik penggantian atau substitusi dan teknik pelepasan atau delisi.

\section{Teknik Oposisi Dua-dua}

Teknik oposisi dua-dua digunakan untuk menyelidiki perbedaan arti leksis antara dua atau lebih satuan lingual, jadi dalam teknik oposisi kontras, perbedaan yang menyangkut 'arti' merupakan tuuan untuk diketahui. Untuk menguji bahwa prefiks $b a$ - ialah pembentuk kala kini, partikel so untuk kala lampau dan partikel mo untuk kala mendatang, maka unsur-unsur tersebut akan dicoba untuk saling mengganti atau dikontraskan guna melihat apakah bentuk dan makna tersebut masih sesuai dengan fungsinya.

Kita da bamanjae baju.

Kita da so manjae baju*

Kita da mo manjae baju.

Dia da basosapu.

Dia da so sosapu.*

Dia da mo sosapu.*

Da orang batangka ikang di koala.

Da orang so tangka ikang di koala.*

Da orang mo tangka ikang di koala. 
Dalam contoh tuturan-tuturan tersebut, setelah dilakukan substitusi unsur pembentuk kala maka partikel so dan mo tidak bisa memberikan makna kala kini seperti yang diberikan oleh prefiks $b a-$. Hal ini bisa dilihat dari ada beberapa tuturan (yang diberi tanda asterik) yang hilang maknanya dan bahkan strukturnya tidak bisa ditemukan atau tidak ada dalam tuturan - tuturan di bahasa Melayu Manado. Sedangkan untuk kala kini, partikel mo dalam beberapa tuturan masih bisa mengganti prefiks $b a$ - dan merubah bentuk kala kini menjadi kala mendatang.

\section{Teknik Pelepasan atau delisi}

Teknik pelepasan atau delisi dimaksudkan akan adanya kemungkinan suatu unsur atau satuan-satuan lingual yang menjadi unsur dari sebuah konstruksi bahasa dalam hal ini tuturan bahasa Melalyu Manado akan dilesapkan atau dihilangkan. Hal ini dilakukan guna mengetahui akibat-akibat struktural apa yang akan terjadi jika salah satu unsur tersebut dihilangkan atau dilesapkan. Jadi, dalam penelitian ini, unsur-unsur yang akan dilesapkan ialah unsur pembentuk kala dalam bahasa Melayu Manado yaitu ba-, so dan mo. Tadi sudah dijelaskan diatas bahwa dalam kala kini dibentuk oleh prefiks $b a$ - yang terikat bersama dengan verba seperti pada contoh 'Da orang batangka ikang di koala.' Jika menghilangkan ba- maka kalimat tersebut menjadi 'da orang tangka ikang di koala'. Tuturan ini masih dapat diterima secara gramatikal, tetapi unsur pemarkah kala dari tuturan ini sudah tidak bisa ditemukan lagi, dalam artian penutur maupun mitra tutur tidak memiliki acuan referensi waktu kapan kegiatan tersebut dilakukan. Hal yang sama juga akan terjadi pada tuturan yang lain, contoh; 'dia da basosapu' menjadi 'dia da sosapu'. Ketika unsur ba- mendapat delisi, maka struktur bahasa dari tuturan ini menjadi tidak gramatikal dan secara semnatis juga tidak berterima. Dari segi struktural, tuturan ini hanya terdiri dari subjek dia, partikel da dan nomina sosapu yang mana secara keseluruhan tuturan ini tidak menjelaskan suatu kegiatan apapun dan tidak memiliki kala. Jika dilihat secara semantis, tuturan ini akan lebih mengarah kepada kata kepunyaan (possisive pronoun). Penerapan teknik pelepasan berikutnya pada kala lampau seperti pada contoh 'Kita so smokol' yang 
akan menjadi 'kita smokol'. Jika partikel so dihilangkan maka tuturan ini hanya akan menjadi 'kita smokol' yang tidak ada atau tidak pernah dituturkan oleh penutur bahasa Melayu Manado sehingga secara struktur maupun semantis tuturan ini tidaklah berterima. Yang terakhir dalam pembentukan kala mendatang selalu menggunakan partikel mo seperti pada tuturan 'Besok mo pi ka Manado' menjadi 'besok pi ka Manado'. Dalam Tuturan ini, biasanya penutur maupun mitra tutur pasti mengetahui bahwa aktifitas tersebut akan dilakukan di waktu yang akan datang, hal ini dikarenakan adanya adverbia waktu. Tetapi jika adverbia waktu didelisi maka kalimat tersebut tidak ada rujukan waktunya. Sebaliknya jika adverbial waktu didelisi tetapi ada partikel mo maka rujukan waktu untuk aktifitas tersebut tetap diketahui seperti 'mo pi ka Manado' yang mana dimengerti bahwa tindakan atau aktifitas ini akan dilakukan dikemudian hari.

\section{KESIMPULAN DAN SARAN}

Dari penelitian ini, dapat diidentifikasi bahwa bahasa Melayu Manado memiliki tiga bentuk kala yaitu kala kini, kala lampau dan kala mendatang. Pembentukan kala dalam bahasa Melayu Manado tersebut dibentuk oleh partikel so, mo dan prefiks ba.

Bentuk kala yang dibentuk oleh partikel so dan diikuti oleh verba yang mana pembentukan ini akan membentuk kala lampau. Partikel mo yang diikuti oleh verba untuk membentuk kala mendatang. Tetapi untuk kala kini pada bahasa Melayu Manado, bentuk dan pembentukkannya memiliki sedikit perbedaan dengan kala lampau dank ala mendatang. Pembentukan kala kini bukanlah dibentuk oleh partikel tetapi dibentuk oleh prefiks $b a$.

Masih ada banyak hal yang dapat dikaji dari bahasa Melayu Manado yang sangatlah bermanfaat untuk diteliti seperti kajian modus dan atau kajian aspek dalam bahasa Melayu Manado yang memang sangat memiliki kaitan yang erat dengan penelitian ini sehingga dapat memberikan gambaran yang lebih jelas akan aspek, kala dan modus dalam bahasa Melayu Manado. 


\section{DAFTAR PUSTAKA}

Bache, Carl 1997. The Study of Aspect, Tense, and Action:Towards a Theory of the

Semantics to Grammatical Categories. Wien: Peter Lang

Bloomfield, Leonard. 1933. Language. New York: Hendri Holt \& Co

Comrie, Bernard 1985. Tense. Cambridge University Press.

Hoed, Benny H. 1992. Kala dalam Novel: Fungsi dan Penerjemahannya.

Yogyakarta: Gadjah Mada University Press

Jespersen Lloyd. 1993. Semantic, Pragmatic, Meaning and Truth: Cambridge:

Cambridge University Press

Kridalaksana, Harimurti. 2001. Kamus Linguistik. Jakarta:

PT Gramedia Pustaka Utama

Lyons, John. 1977. Semantics Volume 2. London: Cambridge University. Press: UK.

Marnetti. 2011. Nomina Isiolek Rantau Sialang. Madah Jurnal Ilmiah Bahasa dan

Sastra. Volume 2 Nomor 1. Edisi April. Riau: Balai Bahasa Provinsi Riau.

Moeliono, Anton. 1988. Tata Bahasa Baku Bahasa Indonesia. Jakarta: Balai Pustaka

Saeed, John L. 1997. Semantics. Oxford: Blackwell Publisher Ltd.

Subroto, Edi. 2007. Pengantar Metode Penelitian Linguistik Struktural. Cetakan 1. Surakarta I UNS dan UNS Press

Supardi. 2011. Afiksasi dalam Bahasa Melayu Papua. Metalingua. Jurnal Bahasa dan

Sastra. Volume 9 Nomor 2. Bandung 